\section{MATHEMATICIANS AND MATHEMATICS AT PRAGUE UNIVERSITY DURING THE SECOND HALF OF THE 18TH CENTURY}

Abstract: The paper describes the situation of teaching mathematics and its position at Prague University in the second half of the 18th century. In order to be able to adequately present the specific changes during this period, I first explain the development of the role of mathematics as a modern science among the Prague Jesuits in the two centuries before. It is pointed out that the Jesuits initially assigned only a very minor importance to mathematics. From the middle of the 17th century, however, there was significant development. In the middle of the 18th century, under the influence of the Enlightenment, state reforms set in, which also significantly influenced the structure and content of education at Prague University. I describe the consequences of these reforms - that also led to the dissolution of the Jesuit Order - for mathematics. Finally, I deal with the life and work of mathematicians and astronomers at Prague University in the second half of the 18th century.

Keywords: mathematics; Jesuits; astronomy; Enlightenment; state reforms

\section{Matematici a matematika na pražské univerzitě v druhé polovině 18. století}

Abstrakt: Článek popisuje výuku matematiky a postavení této vědy na pražské univerzitě $v$ druhé polovinè 18. století. Abych byl schopen adekvátně popsat specifické změny, které nastaly během tohoto období, nejprve stručně představím důležitost matemati$k y$, zvláště pak jejího vývoje $k$ moderni vědě, pro pražské jezuity ve dvou predcházejicích stoletích. Ukáži, že jezuité zpočátku matematice prrikládali jen velmi malý význam. Od poloviny 17. století však začalo docházet $k$ dalekosáhlým změnám. V polovinè 18. století pak byly pod vlivem osvíceneckých idejí nastoleny státní reformy, které výrazně určily strukturu a obsah vzdělávání na pražské univerzitè. Popisuji důsledky těchto reforem, které mimo jiné vedly ke zrušení jezuitského rádu, pro vývoj matematického zkoumání. Na závěr se zabývám životem a prací matematiků a astronomů na pražské univerzitě $v$ druhé polovině 18. století.

Klíčová slova: matematika; jesuité; astronomie; osvícenství; státní reforma

\section{GEORG SCHUPPENER}

Department of Germanic Studies

University of St. Cyril

and Methodius in Trnava

Námestie J. Herdu 2

91701 Trnava, Slovakia

email / georg.schuppener@ucm.sk

(c) (1) This work is licenced under the Creative Commons Attribution 4.0 International License. 


\section{Introduction}

The history of mathematics in Prague and in the Czech lands as a whole has gained more attention in recent decades. This is especially true for the role of the Jesuits in this context. Nevertheless, this topic cannot be considered as conclusively researched as yet. Rather, there are numerous detailed questions that require further investigation.

The aim of this article is not to present any fundamentally new research, but rather to describe the state of the art in a clear and comprehensible form, in order to provide a basis for further research. This is all the more true since most of the research literature is available only in Czech and German and is therefore difficult to access for international, English-speaking academia. Due to the overview character of the article, we will refrain from a dedicated analysis and discussion of the sources as well as from dealing with methodological and source-critical questions.

One focus of the article is to present the direct effects of Enlightenment state reforms on the transformation of the educational system. It is also pointed out that mathematics at the University of Prague reached a good to very good level in the second half of the 18th century.

\section{The Mathematics of the Prague Jesuits until the Middle of the 18th Century}

In 1556 the Jesuits founded their first college in the Czech lands in Prague. After a few years (1562), this foundation gave rise to a Jesuit academy, with a Faculty of Theology and a Faculty of Philosophy, and with its seat in the Clementinum. The aim of the Jesuits' activities in Bohemia, as elsewhere, was to promote the Catholic faith, which was threatened in Central Europe by the Reformation. In the context of this so-called counter-reformation, social elites were to be created through the establishment of educational institutions.

Prague University, founded by Charles IV in 1348, was already strongly influenced by the Hussite movement from the 15th century and later, and from the middle of the 16th century by Reformation forces, too. Against this institution, the newly founded Academy of the Jesuits entered into direct competition. After the victory of the Imperial (Catholic) troops in the Battle of White Mountain, the University was merged with the Jesuit Academy 
(called Ferdinandea) in 1622. However, this union was not very successful and was reversed after a few years (1638). ${ }^{1}$

After the end of the Thirty Years' War, a new university merger took place in 1654, which finally ended the parallel existence of two universities in Prague. The newly created university, the so-called Carolo-Ferdinandea, was de facto dominated by the Jesuits, even if only the Faculties of Philosophy and Theology were in their hands. This constellation lasted until the year 1773, when the Jesuit Order was abolished by Pope Clement XIV. As in other Catholic states in Europe, the Jesuits thus lost their central role in the educational system of the Habsburg Empire. Although the order was re-admitted in 1814, the loss of educational institutions was enormous and the order never regained its former importance in the educational system in Europe. ${ }^{2}$

In the early years, mathematics played only a minor role for the Jesuits in Prague. This can be seen from the fact that the Jesuit Academy did not have a separate professorship for mathematics alone, but rather combined it with that for Hebrew (or another language subject). Moreover, the faculty body changed rapidly, and it was not uncommon that mathematics was taught by people who had just completed their studies.

All this shows that mathematics was not given much attention and no particular importance was attached to it. Rather, the subject, with its subdisciplines of arithmetic, geometry, astronomy and musicology, was probably only taught because this was in keeping with the tradition of the Faculty of Arts. Even the enactment of the study regulations ("Ratio Studiorum"), which were binding for the whole order and came into force in 1599, led only slightly to a qualitative improvement in the mathematical teaching at the Prague Clementinum. ${ }^{3}$

In the second half of the sixteenth century, and to a large extent also in the first half of the seventeenth century, the content of mathematical teaching at Clementinum consisted only of elementary arithmetical and geometrical topics. In addition to this, there were some astronomical questions, which were largely treated in the tradition of ancient natural philosophy. Music

\footnotetext{
${ }^{1}$ See František Kavka and Josef Petráň, eds., A History of Charles University, vol. 1 (Prague: Karolinum, 2001), 264-71.

${ }^{2}$ See Agustín Udías, Jesuit Contribution to Science. A History (Cham: Springer, 2015), 133.

3 The facts summarized here are described in detail in Georg Schuppener: Jesuitische Mathematik in Prag im 16. und 17. Jahrhundert (1556-1654) (Leipzig: Leipziger Universitätsverlag, 1999).
} 
theory, which also belonged to the traditional disciplines of the quadrivium, played no role at all. ${ }^{4}$

However, in the second half of the 17th century and the beginning of the 18th century there was a significant development of mathematics at the University of Prague. The reasons for this development were manifold: The mathematical disciplines gained more and more recognition and importance within the whole order. This was especially true for astronomy. It was recognized that astronomy was of outstanding relevance in the ideological and confessional disputes of the time. The controversy about heliocentric and geocentric world views and the positioning to the arguments of the leading astronomers of that time also had a religious-dogmatic dimension. ${ }^{5}$ It was all the more important for the Jesuits to have their own high authority in this area. By linking their colleges, the Jesuits were able to establish a worldwide network of observation stations, which made the order a leading player in astronomy. This applied not least to the observation of spectacular phenomena, such as solar and lunar eclipses or comets, which were also noticed beyond scientific circles. At the same time, the order had recognized that profound knowledge of mathematics and astronomy was advantageous for its worldwide mission, especially in order to gain access to influential circles, for example in China. ${ }^{6}$

Overall, the study of astronomy and mathematics thus became a major factor in the scientific prestige of the order. The changed, i.e., improved status of mathematics and astronomy was also clearly noticeable at Prague's Clementinum.

On the one hand, there was now a clear focus on astronomy. This becomes clear from the surviving manuscripts. ${ }^{7}$ Important questions here included the occupation with the different planetary models, with time measurement, especially with sundials, the observation and mapping of the moon (selenography) as well as observations with the Camera Obscura or

\footnotetext{
${ }^{4}$ See Karel Mačák and Georg Schuppener, Matematika v jezuitském Klementinu v letech 1600-1740 (Prague: Prometheus, 2001), 33.

${ }^{5}$ See Michel-Pierre Lerner, "L’entrée de Tycho Brahe chez les jésuites ou le chant du cygne de Clavius," in Les Jésuites à la Renaissance. Système éducatif et production du savoir, ed. Luce Giard (Paris: Presses Universitaires de France, 1995), 171.

${ }^{6}$ See, e.g., Gerhard Wilczek, Die Jesuiten in Ingolstadt von 1651 bis 1671. Wiedergabe und Übersetzung des "Summarium de variis rebus Collegii Ingolstadiensis" (Ingolstadt: Stadtarchiv, 1989), 80; Lerner, "Tycho Brahe," 158; Hermann Hoffmann, Schlesische, mährische und böhmische Jesuiten in der Heidenmission (Breslau: Frankes Verlag, 1939), 20.

${ }^{7}$ See Georg Schuppener and Karel Mačák, Prager Jesuiten-Mathematik von 1600 bis 1740 (Leipzig: Leipziger Universitätsverlag, 2002), 151.
} 
telescopes. Spectacular objects such as comets also played a significant role. On the other hand, the professorship of mathematics had meanwhile gained a much more important role, and the mathematical contents concentrated on applied, i.e., practice-oriented topics such as geodesy, stereometry, ballistics, logistics or even questions of architecture and construction. ${ }^{8}$

The 18th century then brought further developments within the Enlightenment, such as the establishment of the natural sciences in the modern sense, which also influenced the mathematical sciences in Prague.

Under the reign of Empress Maria Theresa, far-reaching reforms were carried out throughout the Habsburg educational system, which particularly affected the universities and were intended to lead to a reorganization in the spirit of the Enlightenment. ${ }^{9}$ In the 1740s the empress repeatedly complained about the backwardness of Prague University in particular. ${ }^{10}$

The Theresian reforms of the university sector brought about significant changes at the Prague Faculty of Philosophy, both in the basic order, i.e., in the statutes, as well as in the content of the professorships. While there had been hardly any changes for more than a century, numerous reforms followed in short succession, which led to the transformation of the universities from largely independent corporations to state institutions. ${ }^{11}$ It is particularly noteworthy that the approaches to reform did not come from Prague University itself, but were prescribed from Vienna. The central governmental guidelines thus replaced the previous study contents, which had also been centrally prescribed (albeit by the Jesuit Order).

The reforms were based on a rescript written by the Empress on 20 June 1746 and included, for example, the shortening of the previous three-year philosophy course to just two years. From 1747/48 the "Basic Philosophical Course" comprised experimental physics and metaphysics, speculative

\footnotetext{
8 See Jaroslava Kašparová and Karel Mačák, Utilitas Matheseos. Jezuitská matematika v Klementinu 1602-1773 (Prague: Národní knihovna České republiky, 2002).

${ }^{9}$ See Elisabeth Bradler-Rottmann, Die Reformen Kaiser Joseph II. (Göppingen: Verlag Alfred Kümmerle, 1973), 131. A periodization with reference to Bohemia and Moravia is given by Daniela Tinková, "Osvícenství a věda v českých zemích 18. století," Acta Universitatis Carolinae - Historia Universitatis Carolinae Pragensis 57, no. 2 (2017): 15-29, 21.

${ }_{10}$ See Notker Hammerstein, Aufklärung und katholisches Reich. Untersuchungen zur Universitätsreform und Politik katholischer Territorien des Heiligen Römischen Reichs deutscher Nation im 18. Jahrhundert (Berlin: Duncker und Humblot, 1977), 221.

${ }^{11}$ See Bradler-Rottmann, Die Reformen Kaiser Joseph II., 132.
} 
physics and logic, while the other subjects remained unchanged. In 1749 , logic and speculative physics were transferred to the Philosophy course. ${ }^{12}$

Due to the shortening of the course, numerous elements of speculative philosophy had to be removed from the course. In terms of content, speculative philosophy was reoriented toward practical philosophy. Subjects such as mathematics were to be further developed in terms of content. In addition, the teaching of course content, which was previously based primarily on lectures and dictation, was reformed in that prescribed texts were now to form the basis of the lectures. The establishment of instrument collections, e.g., for experimental physics, was also ordered. In addition, holidays were to be shortened and fluctuation in the teaching staff was to be limited. ${ }^{13}$ The frequent change of Jesuit professors due to the order's internal efforts to exchange members between the various colleges ${ }^{14}$ caused harsh criticism from the government, which demanded a much greater continuity in teaching. ${ }^{15}$ The rapid change can be clearly seen above all in the changes in the subject canon and the denominations of the professorships.

These changes were by no means smooth, and they did not always correspond to the ideas of the Jesuits. ${ }^{16}$ The ideas of the Enlightenment and the concepts of the newly emerging experimental natural sciences were in contradiction to the scientific conception of the order, which was strongly oriented towards Aristotelian philosophy. Moreover, many members of the order understood the studies at the Faculty of Philosophy merely as preparation for a study of theology, which was accompanied by a corresponding low opinion of the subjects concerned.

The objections of the Jesuits against the reforms were eventually overcome. ${ }^{17}$ Nevertheless, resistance to reform was so strong in many areas that the expectations of the reform forces were only partially fulfilled by the Theresian measures and their implementation. ${ }^{18}$

12 See Ivana Čornejová and Anna Fechtnerová, Životopisný slovník pražské univerzity. Filozofická a teologická fakulta 1654-1773 (Prague: Univerzita Karlova, 1986), xx.

${ }^{13}$ See Kavka and Petráń, A History of Charles University, 301; Luboš Nový, ed., Dějiny exaktních věd v českých zemích do konce 19. století (Prague: Nakladatelství Československé akademie věd, 1961), 87.

${ }^{14}$ See Helmuth Gericke, Zur Geschichte der Mathematik an der Universität Freiburg i. Br.

(Freiburg im Breisgau: Verlag Eberhard Albert Universitätsbuchhandlung, 1955), 35.

${ }^{15}$ See Hammerstein, Aufklärung und katholisches Reich, 223.

${ }^{16}$ See Nový, Dějiny exaktních věd, 87.

${ }^{17}$ See Kavka and Petráň, A History of Charles University, 301.

${ }^{18}$ See Hammerstein, Aufklärung und katholisches Reich, 196. 
The reforms were influenced and motivated by a Jesuit-critical, if not even anti-Jesuit attitude, in wide circles at the Habsburg Court, above all in the person of Gerard van Swieten (1700-1772), who, as president of the Commission on Censorship and Studies, was also head of the supreme educational authority and thus largely responsible for the reforms. ${ }^{19}$

\section{Reforms in the Second Half of the 18th Century}

A new reform push began in 1752, which despite the resistance of the Jesuits led to extensive cuts in the previous structures and privileges of the order. In addition to the reaffirmation of the previous reform ideas, such as the introduction of the two-year philosophy course, the office of the Director of Studies was created as the most important innovation on the basis of several new rescripts from 1752. This Director of Studies was to act as a supervisor of the teaching system in the faculty. ${ }^{20}$ In order to involve the Jesuits in the reform process, Jesuits were appointed first as study directors at the Faculties of Philosophy and Theology. At the Faculty of Philosophy in 1752 the famous mathematician Joseph Stepling was the first to assume the position of $\mathrm{Di}$ rector of Studies. ${ }^{21}$ In the case of Stepling it was decisive for his nomination that he was considered one of the most important Enlightenment representatives in the Jesuit Order. Stepling initially refused to accept the post for fear of a possible conflict with his own order, but the order eventually urged acceptance. ${ }^{22}$ Under his presidency, special scientific meetings began in 1753 with lectures on new scientific knowledge in the spirit of the Enlightenment (so-called "consessus philosophicus" or "consessus literarii"). However, these meetings fell died out after a few years. ${ }^{23}$

One of the tasks of the Director of Studies was to organize monthly disputations in the form of questions presented by the Director of Studies and then answered by the doctors of the Faculty of Philosophy. Based on the answers given, the Director of Studies had authority over the academic quality of the faculty members and its assessment. In addition, the Director

\footnotetext{
${ }^{19}$ See Heinz Schilling, Höfe und Allianzen. Deutschland 1648-1763 (Berlin: Wolf Jobst Siedler Verlag, 1994), 318.

${ }^{20}$ See Kavka and Petráň, A History of Charles University, 304.

${ }^{21}$ Ibid.

${ }^{22}$ See Eduard Winter, Der Josefinismus und seine Geschichte. Beiträge zur Geistesgeschichte Österreichs 1740-1848 (Brünn, Munich, Vienna: Rudolf M. Rohrer Verlag, 1943), 68, 73.

${ }^{23}$ See Mikuláš Teich, The Scientific Revolution Revisited (Cambridge: Open Book Publisher, 2015), 70.
} 
of Studies was the supervisor of the so-called "Mathematical Museum" at the Faculty of Philosophy where scientific instruments as well as certain curiosities were collected. ${ }^{24}$

With the Director of Studies, an institution was introduced that functioned as a permanent supervisory body which fundamentally changed the previous power structures at the faculty. The resistance of the Jesuits against this new position, which by the way could be implemented from outside, is therefore understandable.

The office of Director of Studies remained largely unchanged until 1760. Then, however, the office was split up and most of the responsibilities were transferred to the new Director of Studies, the layman Peter Hebenstreit. The previous Director of Studies, Joseph Stepling, controlled only the supervision of mathematics and physics, which he carried out until his death in 1778 .

The reforms also continued in terms of content and methodology: in 1753 a visit to the University of Prague by the Director of the Faculty of Philosophy at the University of Vienna, the mathematician and astronomer Joseph Franz (1704-1776), concluded that the lectures based on peripatetic Aristotelianism had to be terminated and lectures in mathematics and physics could not be successfully given without demonstration. Franz's recommendations were incorporated into a court resolution to the University of Prague in $1754 .{ }^{25}$ This significantly accelerated the Prague Faculty of Philosophy's orientation towards the Enlightenment natural sciences.

By 1755 , the changes were largely completed. See an overview of the teaching areas at the Faculty of Philosophy up to the abolition of the Jesuit Order in $1773: 26$

\footnotetext{
${ }^{24}$ See Kavka and Petráň, A History of Charles University, 304; Otto Seydl, "Dějiny jesuitského 'musea matematického' v koleji sv. Klimenta na Starém městě v Praze," Věstník Královské české společnosti nauk. Tř́da matematicko-přírodovědecká 7 (1951): 1-59; Lubomír Sršeň, "Jezuitské univerzitní teze z Mexika a z Manily ve sbírkách národního muzea v Praze," Miscellanea oddělení rukopisů a starých tisků Národní knihovny České republiky 13 (1996): 72. Some details of the holdings are provided by Petra Hyklová, "Dědictví klementinských exaktních věd a druhý život 'matematického muzea' v 19. a 20. století," Acta Universitatis Carolinae - Historia Universitatis Carolinae Pragensis 57, no. 2 (2017): 45-62, 54.

${ }^{25}$ See Josef Haubelt, České osvícenství (Prague: Nakladatelství Svoboda, 1986), 250.

${ }^{26}$ See Čornejová and Fechtnerová, Životopisný slovník pražské univerzity, XXI.
} 


\begin{tabular}{|l|l|}
\hline $1755-1761$ & $1762-1773 / 74$ \\
\hline Philosophy for the first year & Philosophy for the first year \\
Philosophy for the second year & Philosophy for the second year \\
Rhetoric: & Ethics \\
a) eloquentia sacra & Mathematics \\
b) eloquentia profana & Matheseos sublimioris \\
History: & Oriental languages (until 1763) \\
a) ecclesiastical & Mineralogy (since 1763) \\
b) secular & Fine Arts (since 1763) \\
Greek & Cameralistics and politics \\
Ethics & (since 1768) \\
Mathematics & Rhetoric \\
Oriental languages & Poetics \\
Poetics & \\
\hline
\end{tabular}

Within mathematics, astronomy and meteorology played a particularly important role in its further development. Regular meteorological measurements took place from the middle of the 18th century onwards. The newly equipped observatory was also of special importance. ${ }^{27}$

An important caesura for the activity of the Jesuits at Prague University was the year 1773, when the Jesuit Order was abolished by the papal breve "Dominus ac Redemptor." ${ }^{28}$ This made it possible to remove the universities from Jesuit dominance and put them completely under state control.

This move had several consequences for the Faculty of Philosophy at Clementinum: The Bohemian administration ("Gubernium”), together with the university commission appointed for the reform, ensured that in most subjects, the previous Jesuit teachers were replaced by laymen or members of other orders. Only in mathematics and physics the former professors from the dissolved Jesuit Order were allowed to continue their activities. ${ }^{29}$ The reason for this was that there was a lack of suitable secular teachers who could have directly substituted the Jesuits. ${ }^{30}$ In the area of mathematics, there were initially no personnel changes at Prague University.

\footnotetext{
${ }^{27}$ See Tinková, “Osvícenství a věda v českých zemích 18. století,” 27.

${ }^{28}$ See Alain Guillermou, Ignatius von Loyola (Reinbek: Rowohlt, 1993), 126.

${ }^{29}$ See Kavka and Petráň, A History of Charles University, 306.

${ }^{30}$ See Wolfgang Brezinka, Pädagogik in Österreich. Die Geschichte des Faches an den Universitäten vom 18. bis zum Ende des 20. Jahrhunderts, vol. 1 (Wien: Verlag der Österreichischen Akademie der Wissenschaften, 2000), 10.
} 
The former Jesuits Stanislav Vydra as professor of mathematics, Jan Tesánek as professor of higher mathematics and Joseph Stepling as Director of Studies for mathematics and physics remained in their posts, now as socalled ex-Jesuits. ${ }^{31}$ Moreover, even more ex-Jesuits later achieved influential positions, such as Antonín Strnad, who became professor of mathematics and physical geography in 1778 , or Johannes Diesbach, who was appointed director of mathematical and physical studies after Tesánek's death in $1788 .{ }^{32}$

In this way, the order continued to influence the mathematical disciplines at Prague University for decades after its abolition. Moreover, Catholic clergy remained influential in Prague university mathematics in the first half of the 19th century. Thus, Josef Ladislav Jandera (1776-1857), who succeeded Stanislav Vydra as professor of mathematics at Prague University in 1805 , was a member of the Premonstratensian Order. In 1828, he even became rector of Prague University. And Bernhard Bolzano, holder of the newly established chair of philosophy of religion, although today primarily known as a mathematician, was also a Catholic priest.

The fundamental academic reform that began in 1773 in the Habsburg Empire led to various organizational changes in the following years, but also to changes in content with regard to mathematics: Thus in 1775, in addition to "pure" mathematics in the first year, "applied" mathematics was introduced in the second academic year. Compulsory textbooks for mathematics were also introduced, first (in 1776) the "Mathesis Wolffiana," ${ }^{33}$ later (in 1784) Kästner's textbooks "Anfangsgründe der Arithmetik, Algebra, Geometrie" for the first school year and "Anfangsgründe der angewandten Mathematik" for the second school year. ${ }^{34}$

As far as applied mathematics is concerned, from Vydra's examination papers can be concluded that its contents were mainly elements of mechanics, i.e., subjects such as levers, grinding rollers and pulleys, inclined planes,

${ }^{31}$ See Ivana Čornejová, Tovaryšstvo Ježíšovo. Jezuité v Čechách (Prague: Hart, 2002), 216; Schuppener, Mačák, Prager Jesuiten-Mathematik, 215. The astronomer Zeno could continue to work, too.

${ }^{32}$ See František Kavka and Josef Petráň, eds., Dějiny Univerzity Karlovy II (Prague: Univerzita Karlova, 1996), 104.

${ }^{33}$ The complete title is "Mathesis wolfiana in usum juventutis scholasticae per terras hereditariae Austriacae Domus a suprema studiorum commissione praescripta et a directore facultatis philosoph. Viennensis in compendium redacta." The editor in charge was Joseph Anton Nagel who was director of the Faculty of Philosophy in Vienna at this time.

${ }^{34}$ See Kavka and Petráň, Dějiny Univerzity Karlovy II, 129. Such compulsory textbooks were introduced not only in mathematics but also in other fields. Ibid., 113. 
etc., before which, however, the elements of differential and integral calculus were explained to the students, but these did not take up more than ten percent of the curriculum. ${ }^{35}$ Sometimes other topics were added, such as geometrical optics. However, neither Wolff's nor Kästner's textbook contained elements of differential and integral calculus. ${ }^{36}$

The changes had a negative impact on the "Mathematical Museum": After the dissolution of the Jesuit Order, the library holdings, which were combined into the special collection of the "Mathematical Museum," were set up in the private apartment of Joseph Stepling in the seminary of St. Wenceslas in the Dominikanergasse and returned to the Clementinum only after his death in $1778 .{ }^{37}$

A few years later, more precisely in 1785, the Mathematical Museum was officially dissolved as an institution due to lack of space..$^{38}$ The holdings were subsequently dispersed to other institutions (e.g., to the State Observatory), lost, or publicly auctioned in the middle of the 19th century. ${ }^{39}$ In the historical rooms of the Clementinum only a few pieces remained, including some globes and clocks. ${ }^{40}$

35 See Georg Schuppener and Karel Mačák, Stanislav Vydra (1741-1804). Zwischen Elementarmathematik und nationaler Wiedergeburt (Leipzig: Leipziger Universitätsverlag; Liberec: Technická univerzita Liberec, 2004), 176.

${ }^{36}$ These textbooks by Wolff and Kästner were excerpts from extensive multi-volume compendia of these authors, and Wolff, for example, included a chapter on differential and integral calculus as early as 1713. It is interesting that the manuscript XII G 9b, which is preserved in the National Library in Prague, contains very detailed excerpts (one could almost say transcripts). See Schuppener and Mačák, Prager Jesuiten-Mathematik, 178; Karel Mačák, „Několik poznámek k jezuitským matematickým rukopisům v Národní knihovně České republiky," Miscellanea oddělení rukopisů a starých tiskủ 14 (1997): 31. This could indicate that Wolff's compendia were known and studied in Prague long before the official textbooks were introduced. So, Wolff and Kästner did have chapters on differential and integral calculus, but they were missing in the official textbooks.

${ }^{37}$ See Jan Sajíc, Pokladnice věkủ. Klementinum a universitní knihovna (Prague: Národní a universitní knihovna, 1948), 15; Joseph A. Hanslik, Geschichte und Beschreibung der Prager Universitätsbibliothek (Prague: Buchdruckerei von Friedrich Rohliček, 1851), 69.

${ }^{38}$ See Zdislav Šíma, Astronomie a Klementinum (Prague: Národní knihovna České republiky, 2001), 31; Petr Voit, Pražské Klementinum (Prague: Národní knihovna, 1990), 65.

${ }^{39}$ See Šíma, Astronomie a Klementinum, 31. More detailed information on the whereabouts of the holdings can be found at Hyklová, "Dědictví klementinských exaktních věd," 46.

${ }^{40}$ See Voit, Pražské Klementinum, 66. 


\section{Scholars and Foci of Mathematics in the Second Half of the 18th Century}

The most important and influential personality among the mathematicians of the second half of the 18th century at Prague University was undoubtedly Joseph Stepling (1716-1778). His role in reforming the organization of studies and introducing experimental sciences into the curriculum has already been mentioned, as well as the fact that he was one of those Jesuits who were not hostile, but rather open to the ideas and concepts of the Enlightenment. As Director of Studies of the Faculty of Philosophy, and later only of mathematics and physics, he was in a responsible position of - as one would say today - science management and quality assessment. The supraregional importance of Stepling, whom Zöllner describes as a "prominent representative of the Catholic Enlightenment, ${ }^{\prime \prime 1}$ is demonstrated by his correspondence with Christian Wolff, Leonhard Euler, Rođer Josef Boškovič, Christopher Maire, Nicolas-Louis de Lacaille and several scientists from the Jesuit Order like Franz Huberti or Maximilian Hell. ${ }^{42}$

In general, Stepling is a particularly outstanding example of the fact that "it is necessary to differentiate between the unprogressive attitude of the order delaying the advance of science, and the progressive role of its individual members in furthering and participating in astronomical, mathematical and physical inquiries," especially in Bohemia. ${ }^{43}$

Stepling also had a major influence on further development of astronomy at Clementinum. In his function as Praefectus Speculae astronomicae, for example, he ensured that the so-called mathematical tower of Clementinum was equipped as an observatory. ${ }^{44}$ In particular, he had to decide on the purchase and management of scientific instruments. Some of the instruments

${ }^{41}$ See Erich Zöllner, "Bemerkungen zum Problem der Beziehungen zwischen Aufklärung und Josefinismus," in Der Josephinismus. Bedeutung, Einflüsse und Wirkungen, ed. Helmut Reinalter (Frankfurt: Peter Lang Verlag, 1993), 29.

${ }^{42}$ See Walter Schamschula, Die Anfänge der tschechischen Erneuerung und das deutsche Geistesleben (1740-1800) (Munich: Wilhelm Fink Verlag, 1973), 65. This exchange of letters is published in Josephi Steplingii's Litterarum Commercium (1782). See further Hans-Joachim Vollrath, "Franz Huberti. Steplingův přítel a korespondent," Acta Universitatis Carolinae - Historia Universitatis Carolinae Pragensis 57, no. 2 (2017): 63-69; Josef Smolka and Hans Ullmaier, "Neznámé listy Josefa Steplinga Maximilianu Hellovi," Acta Universitatis Carolinae - Historia Universitatis Carolinae Pragensis 57, no. 2 (2017): 79-89.

${ }^{43}$ Teich, Scientific Revolution Revisited, 70.

${ }^{44}$ See Otto Seydl, “Z nejstarších dějin Pražské hvězdárny,” Český časopis historický 44 (1938): 486-502. Here, a lot of information about Stepling is provided. 
were even imported from England. ${ }^{45} \mathrm{He}$ also contributed to the financing of the observatory from his own funds, so in 1761, after the death of his mother, he dedicated an inheritance of 4,000 florin guilders to this institution.

The environment of his numerous astronomical observations, especially lunar eclipses, also includes several efforts to determine the exact longitude of Prague. He wrote four publications on this topic. ${ }^{46}$

Stepling was also one of the founding fathers of the "Scholarly Society," which from 1775 to 1784 published the "Treatises of a Private Society in Bohemia for the Recording of Mathematics, Patriotic History and Natural History" ("Abhandlungen einer Privatgesellschaft in Böhmen zur Aufnahme der Mathematik, der vaterländischen Geschichte und der Naturgeschichte") ${ }^{47}$ and from which the Bohemian Society of Sciences emerged in $1784 .{ }^{48}$

The mathematical writings of Stepling include, e.g., "Exercitationes geometrico-analyticae de ungulis, aliisque frustis cylindrorum, quorum bases sunt sectiones conicae infinitorum generum" (1751), "Liber II. Euclidis algebraicae demonstratus" (1756), "Miscellanea philosophica tam mathematica quam physica" $(1759,1763)$ and "Differentiarum minimarum quantitatum variantium calculus directus vulgo differentialis" (1765), a rather detailed presentation of differential and integral calculus.

A biography of Stepling was written by Stanislav Vydra, which appeared in Prague in 1779 under the title "Vita admodum reverendi ac magnifici viri Josephi Steplingi."

Stepling's importance is also revealed in the following assessment by Winter: "In the second half of the 18th century, a medical and a mathematical school were established at the university in Prague. While the medical school was only a branch of the Viennese one, the Prague mathematical

\footnotetext{
${ }^{45}$ See Smolka and Ullmaier, "Neznámé listy Josefa Steplinga Maximilianu Hellovi," 80.

${ }^{46}$ See Josef Smolka and Zdislav Šíma, "Josef Stepling (1716-1778) a určování geografické délky Prahy," Acta Universitatis Carolinae - Historia Universitatis Carolinae Pragensis 57, no. 2 (2017): 91-106.

${ }^{47}$ See Jaroslav Prokeš, Počátky české společnosti nauk do konce XVIII. stol., vol. 1 (Prague: Jubilejní fond královské české společnosti nauk, 1938), 57.

${ }^{48}$ See Haubelt, České osvícenství, 353; Prokeš, Počátky české společnosti nauk, 76.
} 
school radiated worldwide. ${ }^{349}$ He sees Stepling as the centre of this school, whereas Bernard Bolzano represented its "culmination." 50

Jan Tesánek (Joannes Tessanek) (1728-1788) took over the newly created chair of higher mathematics in 1762 (according to other sources 1763). Among his students was Franz Josef Gerstner, who followed him in office after his death. In the years 1778-1786 Tesánek, as Stepling's successor, was also director of mathematical and physical studies at the Prague Faculty of Philosophy. He became known especially through his edition of Newton's work "Philosophiae naturalis principia mathematica" (Prague, vol. I, 1780, vol. II, first only a part in 1783 , then completely in 1785$){ }^{51}$

Jan Tesánek attempted to summarize the newest concepts of the basics of differential calculus. From today's point of view it is clear that the basic concept of differential and integral calculus should be the precisely defined concept of limit value and not the vague concepts of infinitely small and infinitely large size. At that time, however, the concept of the limit value was still very unclear. ${ }^{52}$

Tesánek wrote a number of mathematical (mostly geometrical) works as well as a few astronomical treatises, but these had a primarily mathematical background as well. This is the case, for example, of the paper "On Some Properties of the Elliptical Motion of Planets and Comets" ("Von einigen Eigenschaften der elliptischen Bewegung der Planeten und Kometen"), which appeared in 1787 as part of the treatises of the Royal Bohemian Society of Sciences. ${ }^{53}$ In this paper Tesánek reacted to publications by Lagrange and Laplace present at the time. He attempts here to give a new proof and a generalisation of Lambert's theorem. ${ }^{54}$ The Swiss-Alsatian astronomer, physicist, philosopher and mathematician Johann Heinrich Lambert (1728-1777),

${ }^{49}$ Eduard Winter, Barock, Absolutismus und Aufklärung in der Donaumonarchie. (Vienna: Europa Verlag, 1971), 214. The importance of Prague University at that time with regard to mathematics is also emphasised by Luboš Nový, "Matematika na pražské universitě v druhé polovině 18. století," Acta Universitatis Carolinae - Historia Universitatis Carolinae Pragensis 2 (1961): 35 .

${ }^{50}$ See Winter, Barock, Absolutismus und Aufklärung in der Donaumonarchie, 214.

${ }^{51}$ See Luboš Nový, “Jan Tesánek a Newtonova Principia Mathematica Philosophiae Naturalis," Dějiny věd a techniky 35 (2002): 1-21.

${ }^{52}$ See Nový, Dějiny exaktních věd, 97; Luboš Nový, "Matematika v Čechách v 2. polovině 18. století," Sborník pro dějiny př́rodních věd 5 (1960): 81.

${ }^{53}$ See Quido Vetter, "Šest století matematického a astronomického učení na universitě Karlově v Praze,” Věstník královské české společnost nauk, Tř́ída matematicko-přírodovědecká 14 (1953): 17.

${ }^{54}$ See Nový, Dějiny exaktních věd, 106. 
who worked at the Academy of Sciences in Berlin at the end of his life, had developed a method for determining the orbit of comets. His theorem states that the time in which a celestial body travels an arc on a parabolic orbit depends only on the chord of the arc and the sum of the associated radius vectors. While Lambert arrived at the theorem by geometrical means, Lagrange and Laplace tried to calculate the same result by analytical means. ${ }^{55}$

Franz Josef Gerstner (1756-1832) was appointed professor of higher mathematics in the late 1780 s to succeed Tesánek. Gerstner was one of Bolzano's teachers and probably influenced him significantly. ${ }^{56}$ The main focus of his work was on applied mathematics, particularly in the fields of hydrodynamics, transport and mechanics. He became known in the 19th century with several works and initiatives in the field of transport, especially in engineering.

He was also concerned with astronomical questions and, in this context, with the construction of scientific instruments. ${ }^{57}$ In 1785 , he published a paper entitled "On the determination of longitude" ("Über die Bestimmung der geographischen Längen") in which he corrected the longitude of several European cities. His other publications include the textbook "Introduction to Static Architecture" ("Einleitung in die statische Baukunst," Prague 1789).

In 1795, Gerstner was appointed a court assessor and participated in the reorganization of the Austrian curriculum for technical schools. In the same year, he gave the state administration the impetus for the foundation of a technical college, which was then established as the Prague Polytechnic under his direction in 1806.

Beyond mathematics, Stanislav Vydra was also known and influential, particularly through his role in the so-called Czech National Revival. His importance is also due to the fact that he was a professor of mathematics for three decades until his death, influencing more than a generation of students. ${ }^{58}$

\footnotetext{
${ }^{55}$ See Daniel Huber, Versuch über die Verdienste Lambert's in den mathematischen und physischen Wissenschaften (Basel: Schweighauser'sche Buchhandlung, 1829), 49.

${ }^{56}$ See Eduard Winter, Bernard Bolzano und sein Kreis (Leipzig: Verlag von Jakob Hegner, 1933), 6.

${ }^{57}$ See Otto Seydl, Die Geschicke eines Chronometers der Königl. Böhmischen Gesellschaft der Wissenschaften in Prag (1791-1864). Ein Beitrag zur Geschichte der Naturwissenschaften in Böhmen (Prague: Verlag der K. Böhm. Gesellschaft der Wissenschaften, 1935).

${ }^{58}$ The life and work of Vydra were described in detail in Schuppener and Mačák, Stanislav Vydra.
} 
One of his pupils was Bolzano. However, his influence on Bolzano seems to have been rather slight. Vydra plays hardly any role in Bolzano's biographical notes. He is mentioned briefly at one point, but only negatively. Bolzano describes Vydra's way of teaching mathematics as so repulsive that he himself was almost deterred from mathematics for this reason. ${ }^{59}$

Whether Vydra's lectures really gave Bolzano any deeper inspiration for his preoccupation with mathematics, is therefore doubtful. Bolzano's lecture notes, which break off in the middle of a sentence in the second part, show the largely elementary level of Vydra's lectures. ${ }^{60}$

Vydra took up the post of professor of mathematics at Prague University in the autumn of 1772, but de facto did not begin teaching before February $1773 .{ }^{61}$ In this time, mathematics was taught for two hours a week in the first year. ${ }^{62}$ Vydra probably taught using Zeno's textbook (see below) which did not include differential and integral calculus.

Vydra published many papers which document well the breadth of his preoccupation with mathematics. These include over 60 examination papers, the so-called "Tentamina" (or later "Gegenstände"), which he wrote alone or with others. These papers give a good insight into the content of the lessons.

In 1783, Vydra's textbook "Elementa calculi differentialis et integralis" was published in Prague and Vienna. However, it only comprises 88 pages in octavo and two pictorial supplements with 38 illustrations. ${ }^{63}$ The main aim of the textbook was not a theoretical discussion of the basic concepts of differential and integral calculus, but the solution of clearly motivated tasks. If one reads these tasks, one realizes that the majority of them can still be found today in the textbooks on differential and integral calculus for students of various technical faculties.

\footnotetext{
${ }^{59}$ See Bernard Bolzano, Selbstbiographie (Vienna: Wilhelm Braumüller, 1875), 18.

${ }^{60}$ After all, Vydra's lectures also covered the dual system, which is remarkable given the otherwise elementary nature of their contents. The signature of Vydra's lecture notes, preserved at Strahov Monastery ("Vorlesungen aus der Mathematik. Vom Herrn Professor Stanislaus Widra, I-II. Autograf, 22 ll, $4^{\circ}$ ”) is Památník národního písemnictví, Fonds Bernard Bolzano, Sign. C II 14/1-2.

${ }^{61}$ The academic year began at the beginning of November (after All Saints' Day).

${ }^{62}$ See Nový, "Matematika na pražské universitě," 41.

${ }^{63}$ The textbook has already been briefly discussed by Nový, "Matematika na pražské universitě"; Nový, "Matematika v Čechách”; Nový, Dějiny exaktních věd, 92. See also Jaroslav Šedivý, Jiří Mikulčák, and Stanislav Židek, Antologie z učebnic matematiky. Období 1860-1960 (Prague: Státní pedagogické nakladatelství, 1988), 189.
} 
Already a decade before the textbook of differential and integral calculus, Vydra wrote two short papers on this topic. ${ }^{64}$ The first small paper (6 pages) was added to a Tentamen from 1773 under the title "De arithmetica infinitorum." In the following year, 1774, Vydra added a slightly larger paper (14 pages) on the differential and integral calculus to one of his Tentamina, entitled "Primae calculi differentialis et integralis notions."

Vydra also dealt with probability theory to a small extent in an untitled appendix to a Tentamen from 1779, which is probably the first treatise on this theory in the Bohemian lands. Vydra did not set himself any scientific goals here, it is a purely didactic work. The book "Ars conjectandi" (1713) by Jakob Bernoulli, which he quoted, was in the library of the Prague Clementinum since $1727 .{ }^{65}$ According to all known sources, however, it seems that in the 18th century nobody in Bohemia was concerned with probability theory and that the study of this mathematical discipline in the Bohemian lands began only after a very long delay. ${ }^{66}$

Finally, it is worth mentioning that Vydra wrote a "Historia Matheseos in Bohemia et Moravia cultae," published in Prague in 1778, and in a second edition in Leipzig and Frankfurt. This book offers 98 biographies of mathematicians, and according to classical understanding astronomers and physicists are also included.$^{67}$ It is therefore not surprising that special attention is paid to Jesuit mathematicians.

Finally, Johannes Klein, Franz Zeno, Antonín Strnad and Martin Alois David should also be briefly mentioned here.

Johannes Klein (1684-1762), who taught mathematics and astronomy in Prague and was for many years (since 1732) the director of the Mathematical Museum in Clementinum, ${ }^{68}$ made several clocks and other instruments that belonged to the holdings of the Mathematical Museum and also served astronomical purposes. ${ }^{69}$

Franz Zeno (1734-1781) wrote the last Jesuit textbook on mathematics entitled "Elementa algebrae, geometriae, ac trigonometriae" (Prague 1769).

\footnotetext{
${ }^{64}$ See Nový, "Matematika v Čechách," 79.

${ }^{65}$ According to the inscription on the title page of the copy of this book, which is kept in the National Library in Prague under the shelf mark 14 F 43.

${ }^{66}$ See Karel Mačák, "Vývoj teorie pravděpodobnosti v českých zemích do r. 1933," Rozpravy Národního technického muzea v Praze 175. Dějiny vědy a techniky 9 (2002): 5-15.

${ }^{67}$ See Stanislav Vydra, Historia Matheseos in Bohemia et Moravia cultae (Prague: Ioannes Adamus Hagen, 1778).

${ }^{68}$ See Š́ma, Astronomie a Klementinum, 50.

${ }^{69}$ See Seydl, "Dějiny jesuitského 'muzea matematického,” 14.
} 
As the title suggests, its contents were largely traditional. From 1767 to 1772, he held the professorship of mathematics; his successor was Stanislav Vydra. $^{70}$ After Stepling's death he became director of the observatory at Clementinum. ${ }^{71}$

Antonín Strnad (1746-1799) became professor of mathematics and physical geography after Stepling's death in 1778. In 1781 he was appointed professor of astronomy. In 1792 he became dean of the Faculty of Philosophy and in 1795 even rector of the university. He played an important role in the reconstruction of the Astronomical Clock in Prague City Hall.

Finally, Martin Alois David (1757-1836) was professor of metaphysics at the University of Prague and from 1789 adjunct and from 1799 director of the Clementinum Observatory. The most productive time of his scientific activity was in the 19th century, i.e., outside the period considered here. The focal points of his work were meteorology and geodesy. Especially in the field of geodesy he continued the tradition founded by Stepling. ${ }^{72}$

\section{Conclusion}

The second half of the 18th century was a period of significant upswing for mathematics at Prague University. There is no doubt that developments during the Enlightenment contributed to this. Centralization and the associated increased state influence on academia, as well as reforms in the organization and content of studies, ensured that the content of mathematics also underwent significant changes and progress. The study regulations of the Jesuit Order, which had been in force unchanged since 1599, paid relatively little attention to mathematics and this did not necessarily promote innovations. The Enlightenment reforms, however, provided a boost of new ideas, contents and methods. Finally, the establishment of a professorship for higher mathematics can also be seen as an important step towards raising standards. Thus, the study of new mathematical topics and also the mathematical education at University of Prague reached a good to very good level during this period. It is noteworthy that these developments were initiated from outside, but were significantly supported and shaped by Jesuits and ex-Jesuits. And although the most important basic aspects of these development are

${ }^{70}$ Ladislaus Jandera, Rede zur Gedächtnißfeyer des hochwürdigen Herrn Stanislaus Wydra (Prague: Gottlieb Haase, 1816), 16.

${ }^{71}$ See Nový, Dějiny exaktních věd, 104; Seydl, “Z nejstarších dějin Pražské hvězdárny,” 501.

${ }^{72}$ See Smolka and Šíma, "Josef Stepling," 103. 
now well researched, numerous further areas of investigation remain open for research: in addition to detailed studies on the mathematical content and on biographical aspects of the mathematicians of the time, there is still a lack of a comprehensive comparative study on the developments surrounding the abolition of the Jesuit Order, specifically with a focus on mathematics. It should be clarified, especially in comparison with other Jesuit-dominated universities, which concrete parallels and differences to the situation in Prague can be identified and how the effects on mathematics were shaped.

\section{Bibliography:}

Bolzano, Bernard. Selbstbiographie. Vienna: Wilhelm Braumüller, 1875.

Bradler-Rottmann, Elisabeth. Die Reformen Kaiser Joseph II. Göppingen: Verlag Alfred Kümmerle, 1973.

Brezinka, Wolfgang. Pädagogik in Österreich. Die Geschichte des Faches an den Universitäten vom 18. bis zum Ende des 20. Jahrhunderts, vol. 1. Vienna: Verlag der Österreichischen Akademie der Wissenschaften, 2000.

Čornejová, Ivana. Tovaryšstvo Ježíšovo. Jezuité v Čechách. Prague: Hart, 2002.

Čornejová, Ivana, and Anna Fechtnerová. Životopisný slovník pražské univerzity. Filozofická a teologická fakulta 1654-1773. Prague: Univerzita Karlova, 1986.

Gericke, Helmuth. Zur Geschichte der Mathematik an der Universität Freiburg i. Br. Freiburg im Breisgau: Verlag Eberhard Albert Universitätsbuchhandlung, 1955.

Guillermou, Alain. Ignatius von Loyola. Reinbek: Rowohlt, 1993.

Hammerstein, Notker. Aufklärung und katholisches Reich. Untersuchungen zur Universitätsreform und Politik katholischer Territorien des Heiligen Römischen Reichs deutscher Nation im 18. Jahrhundert. Berlin: Duncker und Humblot, 1977.

Hanslik, Joseph A. Geschichte und Beschreibung der Prager Universitätsbibliothek. Prague: Buchdruckerei von Friedrich Rohliček, 1851.

Haubelt, Josef. České osvícenství. Prague: Nakladatelství Svoboda, 1986.

Hoffmann, Hermann. Schlesische, mährische und böhmische Jesuiten in der Heidenmission. Breslau: Frankes Verlag, 1939.

Huber, Daniel. Versuch über die Verdienste Lambert's in den mathematischen und physischen Wissenschaften. Basel: Schweighauser'sche Buchhandlung, 1829. 
Hyklová, Petra. "Dědictví klementinských exaktních věd a druhý život 'matematického muzea' v 19. a 20. století." Acta Universitatis Carolinae - Historia Universitatis Carolinae Pragensis 57, no. 2 (2017): 45-62.

https://doi.org/10.14712/23365730.2018.49.

Jandera, Ladislaus. Rede zur Gedächtnißfeyer des hochwürdigen Herrn Stanislaus Wydra. Prague: Gottlieb Haase, 1816.

Kašparová, Jaroslava, and Karel Mačák. Utilitas Matheseos. Jezuitská matematika v Klementinu 1602-1773. Prague: Národní knihovna České republiky, 2002.

Kavka, František, and Josef Petráň, eds. A History of Charles University, vol. 1. Prague: Karolinum, 2001.

Kavka, František, and Josef Petráň, eds. Dějiny Univerzity Karlovy II. Prague: Univerzita Karlova, 1996.

Lerner, Michel-Pierre. "L'entrée de Tycho Brahe chez les jésuites ou le chant du cygne de Clavius." In Les Jésuites à la Renaissance. Système éducatif et production du savoir, edited by Luce Giard, 145-85. Paris: Presses Universitaires de France, 1995.

Mačák, Karel. "Několik poznámek k jezuitským matematickým rukopisům v Národní knihovně České republiky.” Miscellanea oddělení rukopisů a starých tisků Národní knihovny České republiky 14 (1997): 30-39.

Mačák, Karel. "Vývoj teorie pravděpodobnosti v českých zemích do r. 1933.” Rozpravy Národního technického muzea $v$ Praze 175. Dějiny vědy a techniky 9 (2002): 5-15.

Mačák, Karel, and Georg Schuppener. Matematika v jezuitském Klementinu v letech 1600-1740. Prague: Prometheus, 2001.

Nový, Luboš, ed. Dějiny exaktních věd v českých zemích do konce 19. století. Prague: Nakladatelství Československé akademie věd, 1961.

Nový, Luboš. "Jan Tesánek a Newtonova Principia Mathematica Philosophiae Naturalis.” Dějiny věd a techniky 35, no. 1 (2002): 1-21.

Nový, Luboš. “Matematika na pražské universitě v druhé polovině 18. století.” Acta Universitatis Carolinae - Historia Universitatis Carolinae Pragensis 2 (1961): 35-57.

Nový, Luboš. “Matematika v Čechách v 2. polovině 18. století.” Sborník pro dějiny prírodních věd 5 (1960): 9-113.

Prokeš, Jaroslav. Počátky české společnosti nauk do konce XVIII. stol., vol. 1. Prague: Jubilejní fond královské české společnosti nauk, 1938. 
Sajíc, Jan. Pokladnice věků. Klementinum a universitní knihovna. Prague: Národní a universitní knihovna, 1948.

Schamschula, Walter. Die Anfänge der tschechischen Erneuerung und das deutsche Geistesleben (1740-1800). Munich: Wilhelm Fink Verlag, 1973.

Schilling, Heinz. Höfe und Allianzen. Deutschland 1648-1763. Berlin: Wolf Jobst Siedler Verlag, 1994.

Schuppener, Georg. Jesuitische Mathematik in Prag im 16. und 17. Jahrhundert (1556-1654). Leipzig: Leipziger Universitätsverlag, 1999.

Schuppener, Georg, and Karel Mačák. Prager Jesuiten-Mathematik von 1600 bis 1740. Leipzig: Leipziger Universitätsverlag, 2002.

Schuppener, Georg, and Karel Mačák. Stanislav Vydra (1741-1804). Zwischen Elementarmathematik und nationaler Wiedergeburt. Leipzig: Leipziger Universitätsverlag; Liberec: Technická univerzita Liberec, 2004.

Seydl, Otto. “Dějiny jesuitského 'musea matematického' v koleji sv. Klimenta na Starém městě v Praze.” Věstník Královské české společnosti nauk. Tř́ída matematicko-prírodovědecká 7 (1951): 1-59.

Seydl, Otto. Die Geschicke eines Chronometers der Königl. Böhmischen Gesellschaft der Wissenschaften in Prag (1791-1864). Ein Beitrag zur Geschichte der Naturwissenschaften in Böhmen. Prague: Verlag der K. Böhm. Gesellschaft der Wissenschaften, 1935.

Seydl, Otto. “Z nejstarších dějin Pražské hvězdárny.” Český časopis historický 44 (1938): 486-502.

Smolka, Josef, and Zdislav Šíma. “Josef Stepling (1716-1778) a určování geografické délky Prahy." Acta Universitatis Carolinae - Historia Universitatis Carolinae Pragensis 57, no. 2 (2017): 91-106. https://doi.org/10.14712/23365730.2018.53.

Smolka, Josef, and Hans Ullmaier. "Neznámé listy Josefa Steplinga Maximilianu Hellovi." Acta Universitatis Carolinae - Historia Universitatis Carolinae Pragensis 57, no. 2 (2017): 79-89. https://doi.org/10.14712/23365730.2018.52.

Sršeň, Lubomír. “Jezuitské univerzitní teze z Mexika a z Manily ve sbírkách národního muzea v Praze.” Miscellanea oddělení rukopisů a starých tisků Národní knihovny České republiky 13 (1996): 72-77.

Šedivý, Jaroslav, Jiří Mikulčák, and Stanislav Židek. Antologie z učebnic matematiky. Období 1860-1960. Prague: Státní pedagogické nakladatelství, 1988. 
Šíma, Zdislav. Astronomie a Klementinum. Prague: Národní knihovna České republiky, 2001.

Teich, Mikuláš. The Scientific Revolution Revisited. Cambridge: Open Book Publisher, 2015. https://doi.org/10.11647/OBP.0054.

Tinková, Daniela. “Osvícenství a věda v českých zemích 18. století.” Acta Universitatis Carolinae - Historia Universitatis Carolinae Pragensis 57, no. 2 (2017): 15-29. https://doi.org/10.14712/23365730.2018.47.

Udías, Agustín. Jesuit Contribution to Science. A History. Cham: Springer, 2015. https://doi.org/10.1007/978-3-319-08365-0.

Voit, Petr. Pražské Klementinum. Prague: Národní knihovna, 1990.

Vetter, Quido. “Šest století matematického a astronomického učení na universitě Karlově v Praze.” Věstník královské české společnost nauk, Tř́ída matematicko-přírodovědecká 14 (1953): 1-40.

Vollrath, Hans-Joachim, “Franz Huberti. Steplingův přítel a korespondent.” Acta Universitatis Carolinae - Historia Universitatis Carolinae Pragensis 57, no. 2 (2017): 63-69. https://doi.org/10.14712/23365730.2018.50.

Vydra, Stanislav. Historia Matheseos in Bohemia et Moravia cultae. Prague: Ioannes Adamus Hagen, 1778.

Wilczek, Gerhard. Die Jesuiten in Ingolstadt von 1651 bis 1671. Wiedergabe und Übersetzung des "Summarium de variis rebus Collegii Ingolstadiensis." Ingolstadt: Stadtarchiv, 1989.

Winter, Eduard. Barock, Absolutismus und Aufklärung in der Donaumonarchie. Vienna: Europa Verlag, 1971.

Winter, Eduard. Bernard Bolzano und sein Kreis. Leipzig: Verlag von Jakob Hegner, 1933.

Winter, Eduard. Der Josefinismus und seine Geschichte. Beiträge zur Geistesgeschichte Österreichs 1740-1848. Brünn, Munich, Vienna: Rudolf M. Rohrer Verlag, 1943.

Zöllner, Erich. "Bemerkungen zum Problem der Beziehungen zwischen Aufklärung und Josefinismus.” In Der Josephinismus. Bedeutung, Einflüsse und Wirkungen, edited by Helmut Reinalter, 22-38. Frankfurt: Peter Lang Verlag, 1993. 